\title{
REVIEW
}

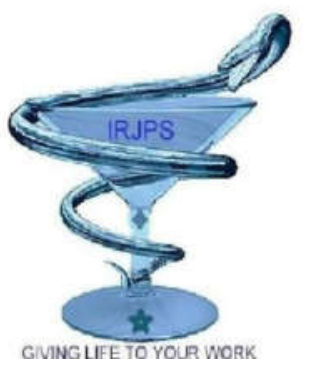

\section{A REVIEW ARTICLE ON PASSIVE SMOKING}

Biplob Dey

Dev Bhoomi Institute of Pharmacy and Research, Dehradun, Uttarakhand, India

\section{Submitted on: 30.09.17; $\quad$ Revised on: 29.10.17; $\quad$ Accepted on: 10.11.17}

\begin{abstract}
:
The purpose of writing this review was to compile the pieces of matter which I have studied from many different national and international articles. In this article $i$ have written about how the passive smoking effects the people, chemical constituents present in Cigarette, its death rate in India and in rest of the world and I have also given some basic introduction on Cancer and its types. Now a days Passive smoking became the major cause of cancer death in all over the world, this may cause different types of cancer like mouth, lungs ,blood ,etc. and it may also cause disease like asthma and many respiratory diseases. Smoking cigarette not only effects the people but also effect the environment like it increases the rate of greenhouse gases and also increases the global warming.
\end{abstract}

KEYWORDS: Smoking, Passive smoker, Active smoker, Cancer, Tobacco, Death.

\section{Corresponding Author: Biplob Dey}

E-mail: biplobdeybkj11@gmail.com
Indian Research Journal of Pharmacy and Science; 14(2017)1164-1169; Journal Home Page: https://www.irjps.in DOI: 10.21276/irjps.2017.4.3.11 


\section{INTRODUCTION: $:^{1,2,3}$}

The first conclusive evidence on the danger of passive smoking came from Takeshi Hirayama's study in 1981 on lung cancer in non-smoking Japanese women married to men who smoked. Cigarette smoking is the main and primary cause of cancer death in all over the world. Different types of cancer caused by cigarette smoking are lungs, stomach, liver, throat, pancreas, mouth, acute myeloid leukaemia etc. Every year nearly millions deaths are Caused due to cigarette smoking in worldwide and approximately 9,00,000people die in India as of 2009 which occupy approximately $12 \%$ of the total death ratein theWorld by WHO. But the question is that is the only people who smoke cigarette aresuffer from Cancer? Theanswerwill be NO because the person who smoke cigarette may suffer from cancer and the person who are standing beside or nearby area may also suffer from cancer. The person who smoke cigarette are known as ACTIVE Smoker and the person who stand beside or any nearby area are known as PASSIVE smoker. So Passive smoking is the inhalation of smoke called second hand smoke (SHS) or Environmental Tobacco Smoke(ETS) by person other than the intended Active smoker. It occur when the Tobacco smoke permeates any environment, causing its inhalation by people within that environment. Every year more than 41,000 people die in USA from Second Hand Smoke Exposer.

"An hour a day in a room with a smoker is nearly a hundred times more likely to cause lung cancer in a non-smoker than 20 years spent in a building containing asbestos. " Sir Richard Doll, 1985

Diseases Cause by Cigarette Smoke: ${ }^{1,5,6,7,8,9,10,}$ 11

1) Cardiovascular Diseases like Stroke, Coronary heart disease, etc
2) Respiratory diseases include COPD which includes emphysema, Chronic bronchitis ,etc.

3) Cancers like Lungs, Mouth, Stomach, Larynx, Pancrease, etc.

4) Other diseases like in women cause Preterm (Early delivery), Stillbirth (Death of the baby before birth), Sudden Infant Death Syndrome, etc.

Chemical Constituents present in Cigarette: Cigarette smoke contains more than $\mathbf{4 0 0 0}$ chemicals, including known 43 cancer causing compounds and 400 other toxins. These cigarette ingredients include Nicotine, Tar, Carbon monoxide as well as ammonia, Hydrogen cyanide, arsenic and DDT. Nicotine is highly addictive, smoke containing Nicotine is inhaled into the lungs and the Nicotine reaches your brain in just 6 seconds.

What is Tobacco? ${ }^{7}$

Tobacco is the most easily assessable legally available addictive substance which contributes significantly to premature death and long term suffering being a major risk factor for Cardiovascular disease, Chronic obstructive pulmonary disease, cancers, reproductive outcomes and oral disease.

In addition one third of the globe burden of oral cancer predominantly attributed to high prevalence of Tobacco consumption within INDIA.

In 2003 over 11,000 people in the UK are estimated to have died by passive smoking Tobacco use kills more than 4,80,000 people each year in the United States.In 1964 the Surgeon General first documented the harmful effects of Smoking. Report of the advisory committee of the Surgeon General of the Public Health Service, which summarised the state of the science knowledge regarding tobacco use, at that time. Research conducted since then has firmly established that 
smoking and other form of tobacco consumption cause an enormous amount of health problem and related death and suffering .According to the 2014 Surgeon General's Report, cigarette smoking today is even more dangerous than previously thought. Cigarette smoking has been linked to disease of nearly all organs of the body, to diminished health status, and to harm to the foetus.

A new England Journal of Medical study ,published in 2013, concluded that compared to those who never smoke, smoker lose at least a decade of Life expectance . Further quitting smoking before 40 reduce the risk of death from continued smoking by about $90 \%$.

Types of Tobacco Smoke: ${ }^{10}$

- Mainstream smoke, which is directly inhaled through the mouth end of the cigarette.
- Side Stream smoke, which comes from the burning tip of the cigarette.

Passive smoke (Second hand) is made up of side stream smoke and exhaled mainstream smoke, mixed with the surrounding air .Side stream smoke is about 4 times more toxic than mainstream smoke, although people inhale it in a more diluted form . This is becauseside stream smoke contains much higher levels of many of the poisons and cancer causing chemicals in cigarettes, including:

- At least 3 times as much carbon monoxide

- 10-30 times more Nitrosamines.

- Between 15-300 times more ammonia

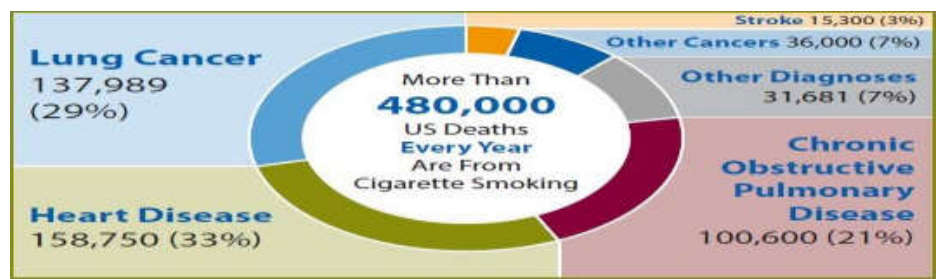

Figure 1: Death by Cigarette Smoke every year

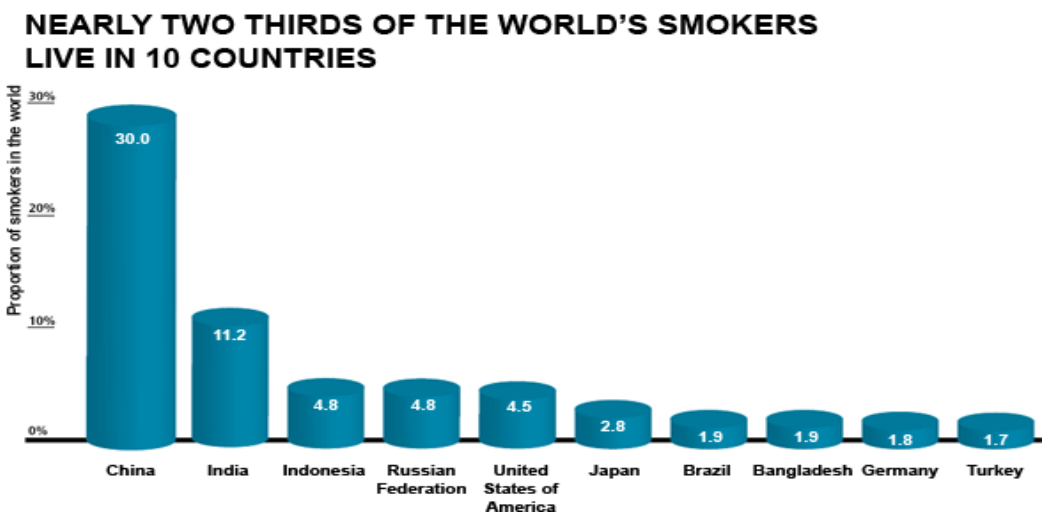

Figure 2: Countries with highest number of Smokers: 


\section{What is Cancer? ${ }^{\mathbf{5 , 1 2}}$}

Cancer is a uncontrolled growth of cell. When the cell is unavailable to divide or loose the ability of cell division then that phase is known as Cancer. Normal cells are constantly subject to signals that command whether the cell should divide , differentiate into ano- ther cell or die.Cancer cell develop a degree of autonomy from these signals resulting in uncontrolled growth and proliferation . If this proliferation is allowed to continue and spread, it can be fatal. In fact, almost $90 \%$ of cancer related deaths are due to tumour spreading-a process called Metastasis.
The two main classification of Cancer are-

- Benign-A benign tumour is a tumour that does not invade its surrounding tissue or spread around the body.

- Malignant-A malignant tumour is a tumour that may invade its surrounding tissue or spread around the body.

\section{Treatments-}

- Surgery: Directly removing the tumor.

- Chemotherapy: Using chemicals to kill cancer cells.

- Radiation therapy: Using X-rays to kill cancer cells.

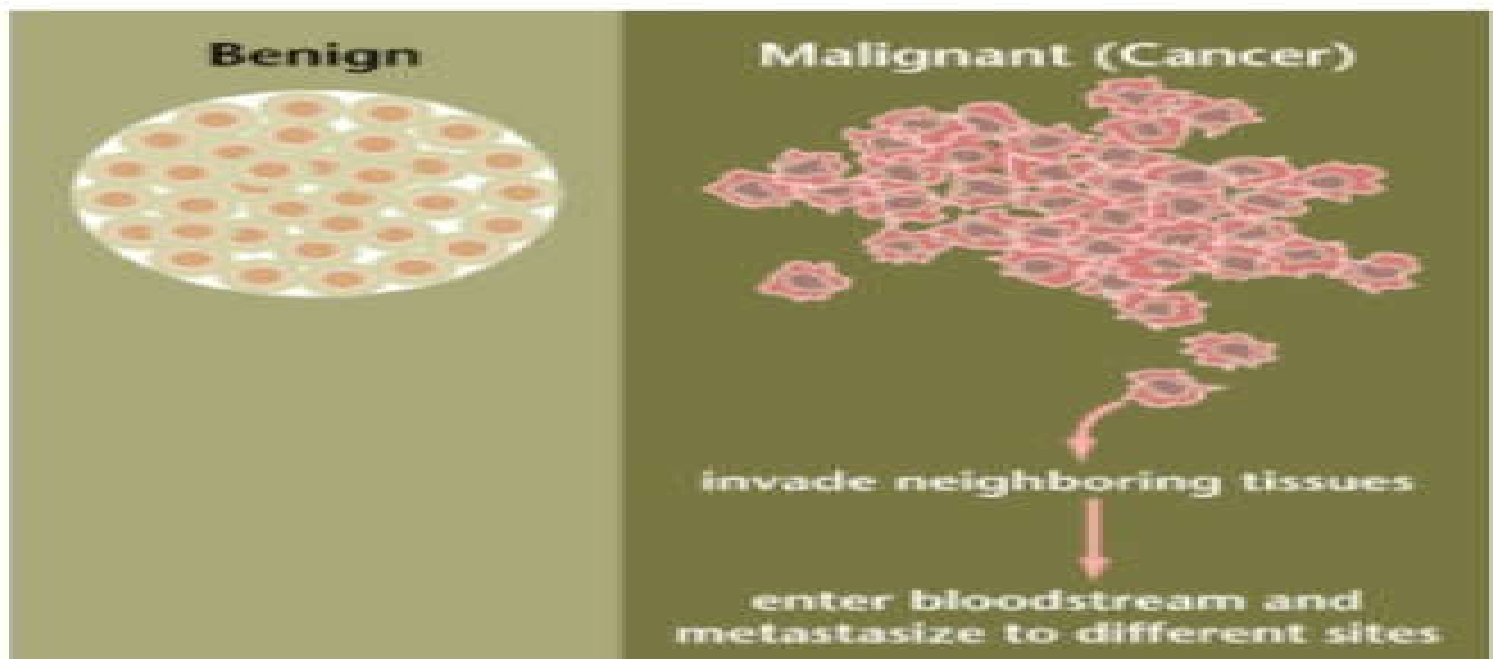

Figure 3: Benign and Malignant Cancer

\section{How does second-hand smoke affect children?}

Second-hand smoke is particularly dangerous for children. Children exposed to passive smoke are at higher risk of respiratory infections, asthma, bacterial meningitis and cot death. Second-hand smoke has been linked to around 165,000 new cases of disease among children in the UK each year.

For children, the majority of exposure to secondhand smoke happens in the home. Smoke can spread throughout the home, even if you open the windows. Almost 85 percent of tobacco smoke is invisible and smoke particles might also build up on surfaces and clothes, although the impact of this is not yet clear. If you are a smoker, smoking outside can help reduce your child's exposure.

\section{Is smoking in cars bad for passengers' health?}

Second-hand smoke can reach very high levels inside cars because it is a small enclosed space. 
During your journey, children in the backseat will be exposed to average smoke levels around three times the European recommended air pollution limit . But the level varies depending on how much you smoke, if you have all the windows fully open or air con on. Peak levels can reach as much as 35 times this limit.
Since 1 October 2015 it has been an offence to smoke in a vehicle carrying anyone under the age of 18 in England and in Wales.

\section{Benefits of stopping smoking:11}

After stopping smoking, the associated health risks diminish substantially in proportion to the period of abstinence, eventually returning to the level of non-smoker rates in some instances.

\begin{tabular}{|c|c|c|}
\hline Disease Category & $\frac{\text { Short-Term Effects }}{(1-5 \text { years })}$ & $\frac{\text { Long-Term } \text { Effects }}{(+5 \text { years })}$ \\
\hline Coronary heart disease & $50 \%$ less risk at 1 year & $\begin{array}{l}\text { Non-smoker rates at } 10 \\
\text { years }\end{array}$ \\
\hline $\begin{array}{l}\text { Peripheral vascular } \\
\text { disease }\end{array}$ & Halts progression & \\
\hline $\begin{array}{l}\text { Cerebrovascular } \\
\text { disease }\end{array}$ & Quick decline in risk & Non-smoker rates at 5 years \\
\hline Lung cancer & $60 \%$ less risk at 5 years & $\begin{array}{l}\text { Non-smoker rates at } 10 \\
\text { years }\end{array}$ \\
\hline Oral cavity cancer & $\begin{array}{l}\text { Risk decreases with } \\
\text { cessation }\end{array}$ & $\begin{array}{l}\text { Non-smoker rates at } 16 \\
\text { years }\end{array}$ \\
\hline Respiratory disease & Slow decline & $50 \%$ less risk at 20 years \\
\hline
\end{tabular}

Table 1: Benefits of Quitting Smoking

\section{DISCUSSION:}

Passive smoking is harmful for people, it also effect the human body organ in the same way as does by Active smoking, rate may be little slower than Active smoking, it may also effect the baby in the mother womb which cause disease like Stillbirth,SIDS,etc

Smoking cigarette is one of the main cause of cancer beside causing cancer it also cause the

\section{REFERENCES:}

1) Wikipedia-Passive smoking.

2) www.cdc.gov/tobacco/data statistics/fast facts/index.html

3) Wikipedia- Smoking in India. www.en.m.wikipedia.org/wiki/Smoking_in_India

4) $\quad$ http://www.rauchstoppzentrum.ch/downlo ads/passivesmoking.pdf respiratory disease, cardiovascular disease, etc. Smoking cigarette not only effect the person who smoke but also effect the people living in that surrounding area which is known as passive smoker. Passive smoking can be prevent by banning cigarette smoking in the public area and making particular room or place for smoking in all the cities. (Example-In Airport there is separate place for smoking).

5) Cancer treatment centres of America http://www.cancercenter.com/what-is-cancer/

6) Cigarette smoke carcinogens Wikipedia https://en.wikipedia.org/wiki/List of cigarette_sm oke carcinogens

7) Burden of Smoked and Smokeless Tobacco Consumption in India - Results from the Global adult Tobacco Survey India (GATS-India)2009-2010 by Gupta Bhawna. 
8) HHS, The Health Consequences of Smoking - 50 Years of Progress: A Report of the Surgeon General,

2014 ,

http://www.surgeongeneral.gov/library/reports/50years-of-progress/

9) K. H. Ginzel, M.D., is Professor of Pharmacology and Toxicology at the University of Arkansas. His work is concentrated in the area of nicotine and its effects

http://www.quitsmokingsupport.com/whatsinit.htm
10) Cancer Research UK

http://www.cancerresearchuk.org/about-

cancer/causes-of-cancer/smoking-and-

cancer/passive-smoking

11) Department of Mental Health and Substance Dependence ,World Health

Organization,1211 Geneva 27, SwitzerlandEncouraging people to stop Smoking.

12) http://study.com/academy/lesson/benignvs-malignant-definition-characteristics-

differences.html Instructor-ArtemCheprasov.

\section{ABBREVIATIONS:}

SHS- Second Hand Smoke.

ETS- Environmental Tobacco Smoke.

COPD- Chronic Obstructive Pulmonary Disease.

SIDS- Sudden Infant Death Syndrome.

DDT- Dichloro diphenyl trichloroethane. 